\title{
Numerical Taxonomy of Rhizobium Strains from Legumes of the Temperate Zone
}

\author{
NATALIE I. NOVIKOVA, ${ }^{*}$ ELENA A. PAVLOVA, NIKOLAI I. VOROBJEV, \\ AND ELENA V. LIMESHCHENKO \\ Research Institute for Agricultural Microbiology, St. Petersburg 189620, Russia
}

\begin{abstract}
Phenotypic properties (growth characteristics, utilization of carbon and nitrogen sources, and intrinsic antibiotic resistance) of $\mathbf{5 3}$ Rhizobium strains isolated from root nodules of the temperate-zone legumes Astragalus spp. (29 strains), Oxytropis campanulata (7 strains), Hedysarum alpinum (7 strains), Ononis arvensis (3 strains), Glycyrrhiza spp. (4 strains), and Coronilla varia (3 strains) were compared with those of other Rhizobium, Bradyrhizobium, and Agrobacterium strains. The final matrix, containing 83 strains and 56 nonsymbiotic features, was used for computer cluster analysis. The dendrogram showed that the new strains of temperate-zone rhizobia formed a cluster separate from both Rhizobium and Bradyrhizobium spp. Two large groups of temperate-zone rhizobia were revealed. Group 1 included rhizobial strains originating from different geographical regions with a temperate climate, while group 2 included strains from the same geographical origin, South Siberia. The strains of recognized Rhizobium species were clustered, in general, with each other as expected from phylogenetic relatedness.
\end{abstract}

Root nodule bacteria of the genera Rhizobium and Bradyrhizobium are a common microflora of temperate soils. These bacteria may interact with the roots of leguminous plants, inducing the formation of nodules in which the fixation of atmospheric nitrogen occurs. These bacteria are commonly used in agriculture for improvement of plant growth. The specificity of the interaction between rhizobia and legumes depends on many factors coded for by the host cultivar and bacterial genomes. The main properties of a bacterial isolate can be described by its taxonomical position in relation to other strains. There are several Rhizobium species recognized at this time $(10,13,24)$, and knowledge of rhizobial evolution and phylogeny obtained in recent studies allows the proposal of new rhizobial taxa $(3,16,25)$. However, the current systematic description of the genus Rhizobium does not include many of the root nodule isolates from legumes of tropical $(22,37)$, arctic $(21)$, and temperate $(5,12,17)$ regions.

The host plant specificities and phage sensitivities of Rhizobium strains from temperate-zone legume root nodules formed on Astragalus, Hedysarum, Glycyrrhiza, and Ononis plants were recently described (17). It was shown that these strains constitute a cross-inoculation group related to Rhizobium loti. The aim of the present work was to determine the cultural properties of these strains and to compare these properties with those of other Rhizobium species.

\section{MATERIALS AND METHODS}

Bacterial strains. Bacterial strains used in this work are listed in Table 1. Bacteria were maintained on yeast extractmannitol (YEM) (29) agar slants at $4^{\circ} \mathrm{C}$.

Growth characteristics. The time necessary for full colony development on YEM agar (estimated here as a colony diameter of $2 \mathrm{~mm}$ ) was determined. Bacterial growth on meat-peptone agar and reactions with litmus milk were determined as described earlier (11). The ability of strains to grow

* Corresponding author. Present address: Centro de Investigacion sobre Fijacion de Nitrogeno, UNAM, Apdo. Postal 565-A, Cuernavaca, Morelos, Mexico. Fax: (73) 1755 81. Electronic mail address: novikova@n2.cifini.unam.mx. in the presence of $0,1,1.5$, or $2 \% \mathrm{NaCl}$ was tested by streaking strains on YEM agar containing the salt. Temperature tolerance was determined by plating strains to obtain single colonies on YEM agar and incubating at 33,35 , and $37^{\circ} \mathrm{C}$ for 7 to 10 days. Unless indicated otherwise, the cultures were incubated at $28^{\circ} \mathrm{C}$. Growth of the fast-growing and slowly growing strains was observed after incubation for 3 to 5 and 5 to 7 days, respectively. All tests were performed in duplicate.

Utilization of carbon sources. For analysis of carbon source utilization, the base medium (YEM) was modified so that yeast extract was replaced by $0.01 \% \mathrm{NH}_{4} \mathrm{NO}_{3}$ and mannitol was replaced by one of the following carbohydrates: sucrose, D-maltose, D-lactose, D-glucose, D-arabinose, D-rhamnose, Dmannose, D-xylose, D-raffinose, dulcitol, D-sorbitol, or the dicarboxylic acid Na-succinate. The media were solidified with $0.7 \%$ agar, and $0.0025 \%$ (wt/vol) bromothymol blue was added as a $\mathrm{pH}$ indicator. The $\mathrm{pH}$ of the media was adjusted to 7.0. Tests were done in tubes.

Utilization of amino acids as sole nitrogen and carbon sources. Tests were performed with the same medium used for the determination of carbon source utilization, but the nitrogen source was replaced by one of the following amino acids $(0.1 \%, \mathrm{wt} / \mathrm{vol})$ as a source of both nitrogen and carbon: L-histidine, DL-valine, L-arginine, L-proline, or DL-serine.

Utilization of mineral nitrogen. The yeast extract in YEM agar was replaced by $0.1 \%$ (wt/vol) of one of the following mineral salts: $\left(\mathrm{NH}_{4}\right)_{2} \mathrm{SO}_{4}, \mathrm{Ca}\left(\mathrm{NO}_{3}\right)_{2},\left(\mathrm{NH}_{4}\right)_{3} \mathrm{PO}_{4}$, or $\left(\mathrm{NH}_{4}\right)_{2}$ $\mathrm{MoO}_{4}$. The media contained $0.0025 \%$ bromothymol blue as a $\mathrm{pH}$ indicator.

Intrinsic antibiotic resistance. Intrinsic antibiotic resistance was tested on YEM agar supplemented with one of the following antibiotics at the indicated concentrations (in micrograms per milliliter): streptomycin, 25,50 , or 100 ; rifampin, 5 , 10 , or 20 ; kanamycin, 10,25 , or 50 ; penicillin, 5 or 10 ; or ampicillin, 5 or 10 .

Nodulation tests. Legume seeds were obtained from the Vavilov Plant Breeding Institute (St. Petersburg, Russia). Tests were done in tubes with surface-sterilized legume seeds as described earlier (17). Twelve seedlings of each legume were inoculated for each strain tested. Tubes were examined for the presence or absence of nodules after 6 weeks. The ability to fix nitrogen was estimated by measuring acetylene-reducing activ- 
TABLE 1. Rhizobial strains used in this work

\begin{tabular}{|c|c|c|c|}
\hline Strain $^{a}$ & Host plant & $\begin{array}{l}\text { Geographical origin and/or } \\
\text { reference }\end{array}$ & Cluster \\
\hline \multicolumn{4}{|l|}{ Bradyrhizobium japonicum strains } \\
\hline CIAM 2490 & Glycine $\max (\mathrm{L}$.$) Merr.$ & Georgia (17) & 1 \\
\hline CIAM 24100 & Glycine $\max (\mathrm{L}$.$) Merr.$ & Georgia (17) & 1 \\
\hline \multicolumn{4}{|l|}{ Bradyhizobium sp. strains (Desmodium) } \\
\hline CIAM 3207 & Desmodium canadense (L.) DC & Ukraine (this work) & 1 \\
\hline CIAM 3208 & Desmodium canadense (L.) DC & Ukraine (this work) & 1 \\
\hline CIAM 3209 & Desmodium canadense (L.) DC & Ukraine (this work) & 1 \\
\hline Rhizobium tropici CIAT $899^{\mathrm{T}}$ & Phaseolus vulgaris $\mathrm{L}$. & Colombia (16) & 2 \\
\hline Agrobacterium tumefaciens biovar 1 C58 & & 2 & 2 \\
\hline Rhizobium fredii USDA 191 & Glycine $\max (\mathrm{L}$.$) Merr.$ & China (34) & 3 \\
\hline Rhizobium sp. strain NGR 234 & Lablab purpureus & New Guinea (27) & 3 \\
\hline Rhizobium huakuii CCBAU 2604 & Astragalus sinicus $\mathrm{L}$. & China (3) & 3 \\
\hline \multicolumn{4}{|l|}{ Rhizobium galegae strains } \\
\hline HAMBI $540^{\mathrm{T}}$ & Galega orientalis Lam. & Finland (13) & 4 \\
\hline CIAM 0703 & Galega orientalis Lam. & Estonia (17) & 4 \\
\hline Agrobacterium radiobacter biovar $2 \mathrm{~K} 84$ & & 2 & 4 \\
\hline Agrobacterium rhizogenes biovar 2 ATCC 15834 & & 20 & 4 \\
\hline \multicolumn{4}{|l|}{ Rhizobium meliloti strains } \\
\hline CIAM 1723 & Medicago sativa $\mathrm{L}$. & Kazakhstan (17) & 5 \\
\hline CIAM 1732 & Medicago sativa $\mathrm{L}$. & Latvia (17) & 5 \\
\hline SU 47 & Medicago sativa $\mathbf{L}$. & Australia (8) & 5 \\
\hline Rhizobium fredii 8613 & Glycine sp. & India (this work) & 5 \\
\hline Rhizobium leguminosanum biovar viciae CB 596 & Pisum sativum $\mathrm{L}$. & England (4) & 6 \\
\hline \multicolumn{4}{|l|}{ Rhizobium loti strains } \\
\hline NZP $2213^{\mathrm{T}}$ & Lotus tenuis Kit. & New Zealand (9) & 6 \\
\hline NZP 2037 & Lotus divaricatus & New Zealand (9) & 6 \\
\hline \multicolumn{4}{|l|}{ Rhizobium huakuii strains } \\
\hline CCBAU 2605 & Astragalus sinicus L. & China (3) & 6 \\
\hline CCBAU $2609^{\mathrm{T}}$ & Astragalus sinicus L. & China (3) & 6 \\
\hline Rhizobium sp. strain CIAM 1413 & Hedysarum alpinum $\mathrm{L}$. & Moscow, Russia (17) & $-b$ \\
\hline \multicolumn{4}{|l|}{ Rhizobium leguminosarum biovar trifolii strains } \\
\hline CIAM 1326 & Trifolium pratense $\mathrm{L}$. & St. Petersburg, Russia (17) & 7 \\
\hline CIAM 1361 & Trifolium hybridum $\mathrm{L}$. & Byelorus (17) & 7 \\
\hline \multicolumn{4}{|l|}{ Rhizobium leguminosarum biovar phaseoli strains } \\
\hline CIAM 2619 & Phaseolus vulgaris L. & Armenia (17) & 7 \\
\hline CIAM 2620 & Phaseolus vulgaris $\mathrm{L}$. & Armenia (17) & 7 \\
\hline \multicolumn{4}{|l|}{ Rhizobium sp. strains } \\
\hline CIAM 0205 & Astragalus uliginosus L. & Vorkuta, Russia (17) & 7 \\
\hline CIAM 0207 & Astragalus falcatus Lam. & Stavropol, Russia (17) & 7 \\
\hline CIAM 0211 & Astragalus uliginosus $\mathbf{L}$. & Altai, Russia (this work) & 8 \\
\hline CIAM 1801 & Lotus corniculatus L. & Moscow (17) & 8 \\
\hline CIAM 3002 & Anthyllis arenaria (Rupr.) Juz. & St. Petersburg (17) & 8 \\
\hline NZP $5462(=$ CC 401) & Coronilla varia $\mathrm{L}$. & United States (4) & 8 \\
\hline CIAM 3502 & Ononis arvensis $\mathrm{L}$. & Lipetsk, Russia (17) & 8 \\
\hline CIAM 3101 & Glycyrhiza glabra L. & Turkmenistan (this work) & 8 \\
\hline CIAM 0201 & Astragalus politovii Kril. & Novosibirsk, Russia (17) & 9 \\
\hline CIAM 0202 & Astragalus frigidus Bge. & Byelorus (17) & 9 \\
\hline CIAM 0203 & Astragalus cicer $\mathrm{L}$. & Byelorus (17) & 9 \\
\hline CIAM 0204 & Astragalus cicer L. & Byelorus (17) & 9 \\
\hline CIAM 0206 & Astragalus uliginosus L. & Vorkuta (17) & 9 \\
\hline CIAM 0208 & Astragalus cicer $\mathrm{L}$. & Ukraine (17) & 9 \\
\hline CIAM 0209 & Astragalus cicer $\mathrm{L}$. & Ukraine (17) & 9 \\
\hline CIAM 0210 & Astragalus cicer $\mathrm{L}$. & Ukraine (17) & 9 \\
\hline CIAM 1406 & Hedysarum alpinum $\mathbf{L}$. & Moscow (17) & 9 \\
\hline CIAM 1410 & Hedysarum alpinum $\mathbf{L}$. & Moscow (17) & 9 \\
\hline CIAM 3503 & Ononis arvensis $\mathrm{L}$. & Lipetsk (17) & 9 \\
\hline CIAM 3505 & Ononis arvensis $\mathrm{L}$ & Lipetsk (17) & 9 \\
\hline CIAM 3118 & Glycynhiza pallidiflora Maxim. & Ukraine (17) & 9 \\
\hline CIAM 3119 & Glycyrrhiza pallidiflora Maxim. & Ukraine (17) & 9 \\
\hline CIAM 3120 & Glycyrhiza pallidiflora Maxim. & Ukraine (17) & 9 \\
\hline CIAM 3402 & Coronilla varia $\mathrm{L}$. & Daghestan (this work) & 9 \\
\hline CIAM 1412 & Hedysarum alpinum $\mathrm{L}$. & Moscow (17) & 10 \\
\hline CIAM 1414 & Hedysarum alpinum $\mathrm{L}$. & Moscow (17) & 10 \\
\hline CIAM 1415 & Hedysarum alpinum $\mathrm{L}$. & Moscow (17) & 10 \\
\hline CIAM 1416 & Hedysarum alpinum $\mathrm{L}$. & Moscow (17) & 10 \\
\hline CIAM 3401 & Coronilla varia $\mathrm{L}$ & Daghestan (this work) & 10 \\
\hline CIAM 1802 & Lotus comiculatus L. & St. Petersburg (17) & - \\
\hline
\end{tabular}


TABLE $1-$ Continued

\begin{tabular}{|c|c|c|c|}
\hline Strain $^{a}$ & Host plant & $\begin{array}{l}\text { Geographical origin and/or } \\
\text { reference }\end{array}$ & Cluster \\
\hline A11 & Astragalus cicer L. & Altai (this work) & 11 \\
\hline A12 & Astragalus cicer L. & Altai (this work) & 11 \\
\hline A14 & Astragalus cicer L. & Altai (this work) & 11 \\
\hline A23 & Astragalus cicer $\mathrm{L}$. & Altai (this work) & 11 \\
\hline A74 & Astragalus uliginosus L. & Altai (this work) & 11 \\
\hline A162 & Astragalus danicus Hetz. & Altai (this work) & 11 \\
\hline CIAM 0214 & Astragalus austrosibiricus B. & Altai (this work) & 11 \\
\hline 252 & Oxytropis campanulata Vass. & Altai (this work) & 12 \\
\hline 253 & Oxytropis campanulata Vass. & Altai (this work) & 12 \\
\hline 254 & Oxytropis campanulata Vass. & Altai (this work) & 12 \\
\hline 256 & Oxytropis campanulata Vass. & Altai (this work) & 12 \\
\hline 257 & Oxytropis campanulata Vass. & Altai (this work) & 12 \\
\hline CIAM 2209 & Oxytropis campanulata Vass. & Altai (this work) & 12 \\
\hline A72 & Astragalus uliginosus L. & Altai (this work) & 13 \\
\hline A161 & Astragalus danicus Hetz. & Altai (this work) & 13 \\
\hline CIAM 0219 & Astragalus danicus Hetz. & Altai (this work) & 13 \\
\hline CIAM 0218 & Astragalus uliginosus L. & Altai (this work) & 13 \\
\hline CIAM 2210 & Oxytropis campanulata Vass. & Altai (this work) & 13 \\
\hline CIAM 0212 & Astragalus falcatus Lam. & Altai (this work) & 14 \\
\hline CIAM 0213 & Astragalus danicus Hetz. & Altai (this work) & 14 \\
\hline CIAM 0215 & Astragalus falcatus Lam. & Altai (this work) & 14 \\
\hline A32 & Astragalus falcatus Lam. & Altai (this work) & 14 \\
\hline A172 & Astragalus danicus Hetz. & Altai (this work) & 14 \\
\hline A173 & Astragalus danicus Hetz. & Altai (this work) & 14 \\
\hline A174 & Astragalus danicus Hetz. & Altai (this work) & 14 \\
\hline
\end{tabular}

${ }^{a}$ CIAM, strain obtained from the culture collection of the Research Institute for Agricultural Microbiology, St. Petersburg, Russia. Strains of $R$. huakuii were recieved from E.-T. Wang (Beijing Agricultural University, Beijing, China). Other Rhizobium strains were provided by K. Lindstrom (University of Helsinki, Helsinki, Finland). T, type strains of species.

$b$-, Strain not part of a cluster.

ity. In all plant tests, uninoculated plants were included as controls.

Numerical analysis. A computer cluster analysis of 56 phenotypic nonsymbiotic variables for 83 strains was performed by using the weighed complete-linkage method as described earlier $(26,28)$.

The data were coded for bacterial growth characteristics as follows: 0 for an absence of growth, 1 for light growth, and 2 for heavy growth. Changes in the $\mathrm{pH}$ of the culture media were assigned values of -2 for strong acidification, -1 for a weak acidification, 0 for no change, 1 for weak alkalinization, and 2 for strong alkalinization. Reactions on litmus milk were given values of 0 for the absence of a serum zone and 2 for the presence of a serum zone. Growth rate values were assigned on the basis of the number of days it took for full colony development to occur. Weighting coefficients used were 4 for acidity of culture media, 10 for growth rates, and 2 for other characters.

The characters with a dispersion of 0 were excluded from the calculations. The analysis was performed at the Computer Laboratory, Research Institute for Agricultural Microbiology, St. Petersburg, Russia.

\section{RESULTS}

Computer analysis allowed us to group the strains into 14 clusters on the basis of their metabolic properties. The composition of each cluster is shown in Table 1 . A dendrogram showing the linkage between clusters is presented in Fig. 1. The strains under investigation formed two large taxonomic groups with a 0.44 level of similarity. These groups were found to be divergent both from other Rhizobium species and from Bradyrhizobium strains. The level of similarity between these groups and the Rhizobium reference strains was about 0.33 , and the level of similarity between Bradyrhizobium and Rhizobium species was less than 0.3 . The metabolic properties of the strains are presented in Table 2.

Cluster 1 included slowly growing Bradyrhizobium strains isolated from root nodules of Desmodium canadense and Glycine max. This cluster has the greatest divergence from the other rhizobia tested.

Cluster 2 consisted of only two strains: Rhizobium tropici CIAT 899 and Agrobacterium tumefaciens C58. Cluster 3 comprised strains having different taxonomical positions: Rhizobium fredii USDA 191, Rhizobium huakuii CCBAU 2604, and Rhizobium sp. strain NGR 234. Cluster 4 included four strains: two strains of Agrobacterium and two strains of Rhizobium galegae. Cluster 5 is composed of Rhizobium meliloti as well as $R$. fredii strains. It should be noted that strains from different geographical origins but belonging to the same taxon were, as a rule, clustered with one another. Cluster 6 comprised the related strains of $R$. loti and $R$. huakuii. Clusters 2 through 6 united into one taxonomic group with a level of similarity of about 0.5 . This group included nearly all of the Rhizobium and Agrobacterium reference strains used in this work.

Two Rhizobium strains (CIAM 1413 and CIAM 1802) were not clustered with one another or with other bacteria tested and occupied distinct positions on the dendrogram.

Cluster 7 included two Rhizobium strains isolated from root nodules of Phaseolus vulgaris, two strains identified as Rhizobium leguminosarum bv. trifolii, and two isolates from root nodules formed on an Astragalus sp. This cluster was more related to the Rhizobium sp. strains under investigation than to the reference strains. 
Level of similarity

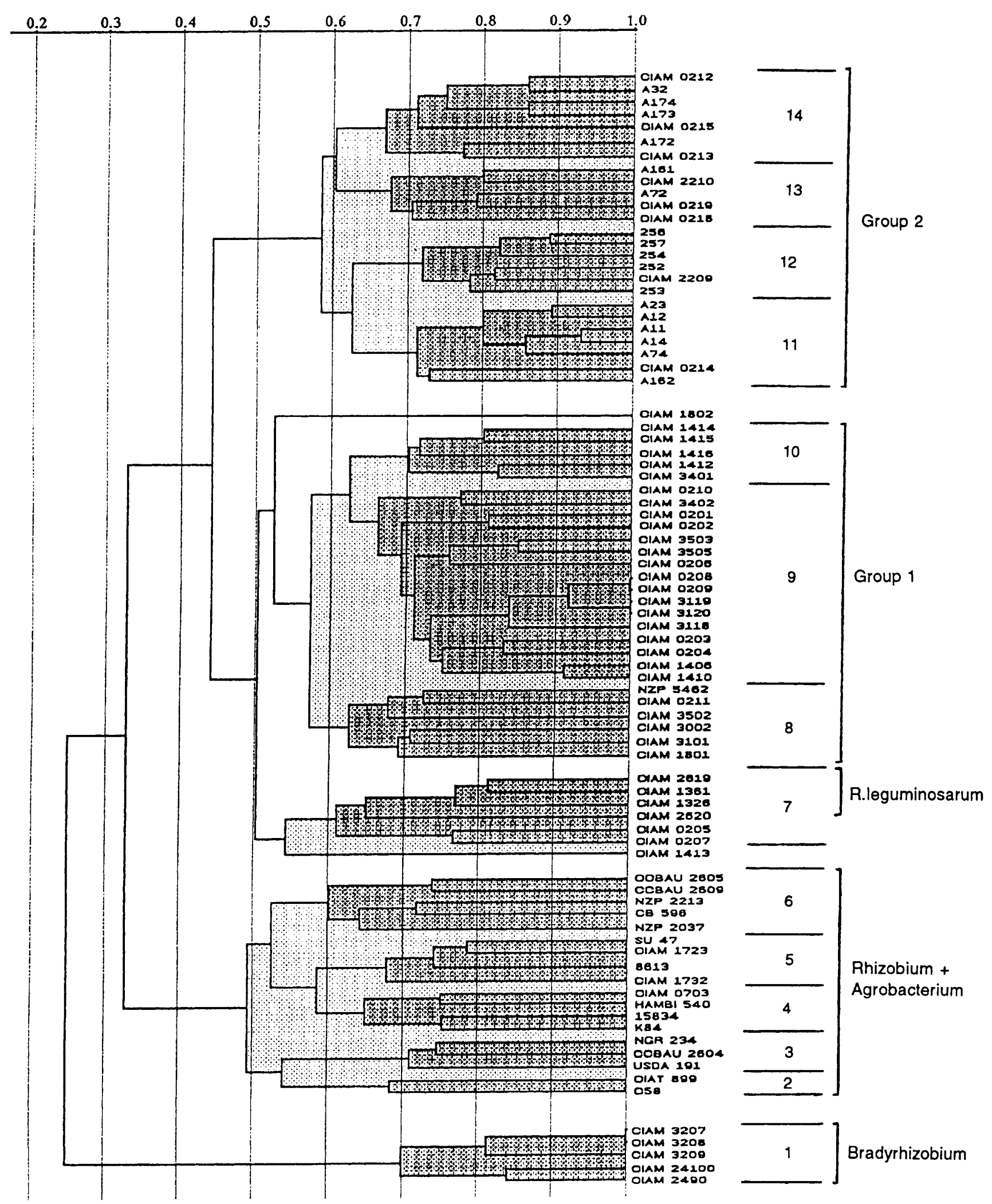

FIG. 1. Dendrogram reflecting phenotypic similarities between Rhizobium strains from temperate-zone legumes and other Rhizobium,

Agrobacterium, and Bradyrhizobium strains.

Clusters 
TABLE 2. Metabolic properties of clustered strains ${ }^{a}$

\begin{tabular}{|c|c|c|c|c|c|c|c|c|c|c|c|c|c|c|}
\hline \multirow{2}{*}{ Characteristic } & \multicolumn{14}{|c|}{ Cluster $(n)$} \\
\hline & $1(5)$ & $2(2)$ & $3(3)$ & $4(4)$ & $5(4)$ & $6(5)$ & $7(6)$ & $8(6)$ & $9(16)$ & $10(5)$ & $11(7)$ & $12(6)$ & $13(5)$ & $14(7)$ \\
\hline \multicolumn{15}{|c|}{$\begin{array}{l}\text { Acidification of medium containing the } \\
\text { following carbon sources: }\end{array}$} \\
\hline D-Arabonose & - & + & + & + & + & + & + & + & + & + & 2 & 3 & 1 & 2 \\
\hline D-Glucose & 4 & + & + & + & + & + & + & + & 14 & + & + & + & + & + \\
\hline D-Lactose & - & + & + & + & + & + & + & + & + & + & + & + & + & + \\
\hline D-Maltose & 3 & + & + & 3 & + & + & + & + & + & + & + & + & + & + \\
\hline D-Mannose & - & + & + & + & + & + & + & 5 & + & + & 5 & + & 2 & 5 \\
\hline D-Rhamnose & - & + & + & + & + & + & + & + & + & + & 6 & 3 & 1 & + \\
\hline D-Raffinose & - & + & + & + & + & 3 & - & - & - & - & - & - & - & - \\
\hline D-Sorbitol & - & + & + & 3 & + & + & + & + & + & + & + & + & + & + \\
\hline D-Xylose & - & + & 2 & 3 & 2 & + & 2 & 1 & - & 2 & + & + & 4 & + \\
\hline Dulcitol & - & 1 & - & 3 & + & 4 & + & + & + & + & 6 & + & 1 & + \\
\hline Na-succinate & - & - & - & - & - & - & - & - & - & - & - & - & - & - \\
\hline Sucrose & - & + & + & 2 & + & + & + & + & + & + & + & + & + & + \\
\hline \multicolumn{15}{|c|}{$\begin{array}{l}\text { Acidification of medium containing the } \\
\text { following nitrogen sources: }\end{array}$} \\
\hline $\mathrm{Ca}\left(\mathrm{NO}_{3}\right)_{2}$ & - & 1 & 1 & + & + & 2 & + & 3 & 14 & 2 & + & 1 & + & 6 \\
\hline$\left(\mathrm{NH}_{4}\right)_{2} \mathrm{SO}_{4}$ & - & + & + & + & + & + & + & + & + & + & + & + & + & + \\
\hline$\left(\mathrm{NH}_{4}\right)_{3} \mathrm{PO}_{4}$ & - & + & + & + & + & + & + & + & + & + & + & 5 & + & + \\
\hline$\left(\mathrm{NH}_{4}\right)_{2} \mathrm{MoO}_{4}$ & - & + & + & + & + & + & + & + & + & + & + & + & + & + \\
\hline \multicolumn{15}{|c|}{$\begin{array}{l}\text { Alkalinization of medium containing the } \\
\text { following amino acids: }\end{array}$} \\
\hline L-Arginine & 4 & - & - & 3 & 2 & - & + & + & + & + & + & + & + & 6 \\
\hline L-Histidine & + & 1 & - & + & 3 & 1 & + & + & + & + & + & + & + & + \\
\hline L-Proline & + & - & - & - & - & - & 5 & + & + & + & + & + & + & 6 \\
\hline DL-Serine & 4 & 1 & - & - & - & - & 2 & + & 11 & 2 & 6 & 1 & - & - \\
\hline DL-Valine & - & + & + & - & 3 & + & - & - & - & - & - & - & - & - \\
\hline \multicolumn{15}{|l|}{ First colony formed after: } \\
\hline $2-3$ days & - & + & - & + & + & - & + & - & - & - & - & - & - & - \\
\hline 4-5 days & - & - & + & - & - & + & - & - & - & - & + & - & - & - \\
\hline $5-6$ days & - & - & - & - & - & - & - & + & - & - & - & - & - & + \\
\hline $6-7$ days & - & - & - & - & - & - & - & - & + & + & - & + & + & - \\
\hline 8 days & + & - & - & - & - & - & - & - & - & - & - & - & - & - \\
\hline \multicolumn{15}{|l|}{ Growth at: } \\
\hline $33^{\circ} \mathrm{C}$ & + & + & + & + & + & + & + & + & + & - & 6 & - & - & - \\
\hline $35^{\circ} \mathrm{C}$ & + & + & + & + & + & + & 4 & + & 6 & - & - & - & - & - \\
\hline $37^{\circ} \mathrm{C}$ & + & + & 2 & 1 & + & 3 & 3 & 5 & 1 & - & - & - & - & - \\
\hline Growth on MPA $^{b}$ & - & + & - & - & + & - & - & - & - & - & - & - & - & - \\
\hline \multicolumn{15}{|l|}{ Intrinsic antibiotic resistance } \\
\hline \multicolumn{15}{|l|}{ Ampicillin } \\
\hline $5 \mathrm{mg} /$ liter & - & + & + & + & + & 4 & + & 4 & 2 & - & - & - & - & 3 \\
\hline $10 \mathrm{mg} /$ liter & - & 1 & 2 & 3 & + & 4 & + & 3 & 2 & - & - & - & - & - \\
\hline Kanamycin & & & & & & & & & & & & & & \\
\hline $10 \mathrm{mg} /$ liter & + & 1 & 1 & + & 3 & 4 & 2 & + & + & + & 4 & 4 & 2 & 1 \\
\hline $25 \mathrm{mg} / \mathrm{liter}$ & + & - & 1 & + & 1 & 4 & - & 3 & 13 & + & 1 & - & - & - \\
\hline $50 \mathrm{mg} /$ liter & - & - & - & - & 1 & 1 & - & - & 2 & - & - & - & - & - \\
\hline Penicillin & & & & & & & & & & & & & & \\
\hline $5 \mathrm{mg} / \mathrm{liter}$ & - & 1 & + & + & + & + & 5 & 2 & 4 & 1 & - & - & - & 3 \\
\hline $10 \mathrm{mg} /$ liter & - & 1 & + & + & + & + & 4 & 1 & 2 & 1 & - & - & - & - \\
\hline Rifampin & & & & & & & & & & & & & & \\
\hline $5 \mathrm{mg} /$ liter & + & + & - & - & - & + & - & 2 & 1 & 1 & - & - & - & - \\
\hline $10 \mathrm{mg} /$ liter & + & + & - & - & - & + & - & 1 & - & - & - & - & - & - \\
\hline $20 \mathrm{mg} /$ liter & + & + & - & - & - & 2 & - & - & - & - & - & - & - & - \\
\hline Streptomycin & & & & & & & & & & & & & & \\
\hline $25 \mathrm{mg} /$ liter & 4 & + & 1 & 1 & 1 & 2 & - & 1 & - & - & - & - & - & - \\
\hline $50 \mathrm{mg} /$ liter & - & + & 1 & - & & & & & & & & & & \\
\hline $100 \mathrm{mg} /$ liter & - & 1 & - & - & - & - & - & - & - & - & - & - & - & - \\
\hline $\mathrm{NaCl}$ tolerance & & & & & & & & & & & & & & \\
\hline $1.0 \%$ & 3 & + & + & + & + & 4 & 4 & + & 15 & + & + & + & + & + \\
\hline $1.5 \%$ & - & + & 2 & + & + & 3 & 4 & 3 & 6 & 2 & 5 & 1 & 3 & 3 \\
\hline $2.0 \%$ & - & + & - & 3 & + & 2 & 1 & 1 & - & - & - & - & - & - \\
\hline Reaction with litmus milk & & & & & & & & & & & & & & \\
\hline Medium alkalinity & + & 1 & 1 & 2 & 1 & + & 5 & 2 & 10 & 2 & + & + & + & + \\
\hline Serum zone & - & + & + & 2 & + & + & 2 & + & + & + & + & - & 4 & + \\
\hline $\begin{array}{l}\text { Utilization of the following a } \\
\text { sole nitrogen and carbor }\end{array}$ & & & & & & & & & & & & & & \\
\hline L-Arginine & + & + & + & + & + & + & + & + & + & + & + & + & + & + \\
\hline
\end{tabular}


TABLE 2-Continued

\begin{tabular}{|c|c|c|c|c|c|c|c|c|c|c|c|c|c|c|}
\hline \multirow{2}{*}{ Characteristic } & \multicolumn{14}{|c|}{ Cluster $(n)$} \\
\hline & $1(5)$ & $2(2)$ & $3(3)$ & $4(4)$ & $5(4)$ & $6(5)$ & $7(6)$ & $8(6)$ & $9(16)$ & $10(5)$ & $11(7)$ & $12(6)$ & $13(5)$ & $14(7)$ \\
\hline L-Histidine & + & + & + & + & + & + & + & + & + & + & + & + & + & + \\
\hline L-Proline & + & + & + & + & + & + & + & + & + & + & + & + & + & + \\
\hline DL-Serine & + & + & + & + & + & 4 & + & + & 13 & 2 & + & 5 & 2 & 5 \\
\hline DL-Valine & + & + & + & 3 & + & + & 2 & 5 & 3 & 1 & 1 & 1 & - & 1 \\
\hline \multicolumn{15}{|c|}{$\begin{array}{l}\text { Utilization of the following carbon } \\
\text { sources: }\end{array}$} \\
\hline D-Arabinose & + & + & + & + & + & + & + & + & + & + & 2 & 3 & 1 & 2 \\
\hline D-Lactose & + & + & + & + & + & + & + & + & + & + & 6 & + & + & + \\
\hline D-Mannose & + & + & + & + & + & + & + & + & + & + & + & + & 4 & 5 \\
\hline D-Rhamnose & + & + & + & + & + & + & + & + & + & + & + & + & 2 & + \\
\hline D-Xylose & + & + & + & + & 2 & + & 3 & 2 & - & 2 & 6 & + & 4 & + \\
\hline
\end{tabular}

$a+$, all strains were positive; -, all strains were negative. Numerical values are the number of positive strains of the total number of strains tested.

${ }^{b}$ MPA, meat-peptone agar.

Three clusters (clusters 8,9 , and 10) formed the first taxonomic group of temperate-zone rhizobia, with a 0.57 level of similarity. The central strains of this group were CIAM 0208 and CIAM 0209. Cluster 8 consisted of six strains isolated from root nodules formed on temperate-zone legumes of various genera (Lotus, Anthyllis, Glycyrrhiza, Astragalus, Ononis, and Coronilla). Cluster 9 was the most extensive one and contained 16 strains isolated from diverse legumes from different geographical regions. Cluster 10, bordering cluster 9, included five strains specific for nodulating Hedysarum alpinum and Coronilla varia.

Four clusters (clusters 11, 12, 13, and 14) made up the second taxonomical group, with a 0.58 level of similarity. This group included only strains isolated from the root nodules of Astragalus and Oxytropis plants found in Siberia. The central strain of this group is CIAM 0219.

The characteristics that differentiate these newly discovered phenotypic groups from existing Rhizobium species are presented in Table 3. The strains under investigation were attributed to the genus Rhizobium (they grew rapidly on YEM media, did not produce alkali on sugar media, and utilized a wide range of carbon compounds [10]), while for most of the characteristics studied they had features intermediate between those the fast- and slow-growing root nodule bacteria.

Data on the plant host ranges of representative strains of group 2 as well as bacteria isolated from root nodules of $C$. varia (group 1) are presented in Table 4 . Host specificities of other temperate-zone rhizobia included in group 1 have been described previously (17). The results show that the plant host ranges of these rhizobial strains of different temperate-zone geographical origins are similar and include several temperatezone legumes (Table 4), but no nodules were formed on roots of Medicago sativa, Trifolium pratense, or Galega orientalis plants inoculated with these strains.

\section{DISCUSSION}

The family Leguminosae, one of the largest plant families, contains about 20,000 different species distributed from arctic to tropical latitudes. Only a small portion of legume species (less than $15 \%$ ) have been screened for ability to be nodulated $(1,6)$. Therefore, many bacterial legume microsymbionts remain uninvestigated.

In recent years, progress towards the development of a more complete Rhizobium taxonomy has been made, and new species have been described: $R$. tropici (16), $R$. huakuii (3), and
Rhizobium etli (25). Genomic relatedness between members of the family Rhizobiaceae has been revealed by modern approaches and has allowed the construction of phylogenetic trees and the proposal of possible modes of rhizobial evolution $(7,14,31,33,35)$. The data gathered to date show that the family Rhizobiaceae is composed of phylogenetically heterogenous genera. Thus, Bradyrhizobium spp. are more related to nonsymbiotic bacteria such as Rhodopseudomonas, Afipia, and Nitrobacter spp. (19, 31-33); Rhizobium spp. are related to Agrobacterium, Brucella, and Bartonella spp. (33). These facts indicate the need for a revision of existing taxa of the family $(31,33)$ as well as the likelihood of discovery of new forms of root nodule bacteria.

The present work centered on the study of root nodule bacteria isolated from the temperate-zone legumes of the genera Astragalus, Oxytropis, Glycyrrhiza, Ononis, Hedysarum, and Coronilla. Previous analyses of the phage sensitivities and plant host ranges of these isolates indicated that they are related to strains isolated from root nodules formed on Lotus corniculatus, and so they were classified as $R$. loti (17). In this work, a comparison of the metabolic properties of the bacteria was performed, and cluster analysis was used to construct a dendrogram reflecting the phenotypic relationships among these strains. A significant distance was found between the Rhizobium strains under investigation and the reference strains included in the study. In addition, two large groups were identified among the temperate-zone rhizobia studied. Group 1 included rhizobial strains originating from different geographical regions of the temperate zone, while group 2 included strains from the same geographical origin, South Siberia.

None of the rhizobial isolates obtained from temperate-zone legumes (including bacteria from $L$. corniculatus nodules) were clustered with the $R$. lot $i$ type strain NZP2213 or with other $R$. loti or $R$. huakuii strains. These strains, however, have spectra of phage sensitivity similar to those of the temperate-zone rhizobia (data not presented).

It should be mentioned that taxonomic group I included strain NZP 5462, which was isolated from the root nodules of $C$. varia. This strain was used earlier in DNA-DNA hybridization studies and was demonstrated to have not more than $10 \%$ DNA homology with the $R$. loti type strain and about $20 \%$ homology with strains of the $R$. leguminosarum group (4). The present work shows that the Rhizobium strains most closely related to the temperate-zone rhizobia described here were $R$. leguminosarum strains of the same geographic origin. 
TABLE 3. Metabolic features differentiating rhizobial species ${ }^{a}$

\begin{tabular}{|c|c|c|c|c|c|c|c|c|c|}
\hline Characteristic & Group 1 & Group 2 & 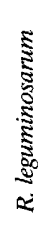 & 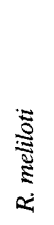 & 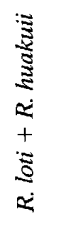 & 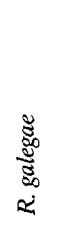 & 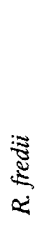 & 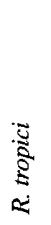 & 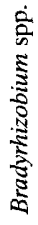 \\
\hline \multicolumn{10}{|l|}{$\begin{array}{l}\text { Acidification of medium containing the } \\
\text { following carbon sources: }\end{array}$} \\
\hline D-Arabinose, D-ramnose, or D-mannose & + & $\mathrm{d}$ & + & + & + & + & + & + & - \\
\hline D-Xylose & $\mathrm{d}$ & + & $\mathrm{d}$ & $\mathrm{d}$ & + & $\mathrm{d}$ & $\mathrm{d}$ & + & - \\
\hline $\begin{array}{l}\text { Acidification of medium containing mineral } \\
\text { nitrogen sources }\end{array}$ & + & + & + & + & + & + & + & + & - \\
\hline \multicolumn{10}{|l|}{$\begin{array}{l}\text { Alkalinization of medium containing the } \\
\text { following amino acids: }\end{array}$} \\
\hline L-Histidine & + & + & + & $\mathrm{d}$ & $\mathrm{d}$ & + & $\mathrm{d}$ & + & + \\
\hline L-Proline & + & + & $\mathrm{d}$ & - & - & - & - & - & + \\
\hline DL-Serine & $\mathrm{d}$ & $\mathrm{d}$ & $\mathrm{d}$ & - & - & - & - & - & $\mathrm{d}$ \\
\hline \multicolumn{10}{|l|}{ First colony formed after: } \\
\hline $2-3$ days & - & - & + & + & - & + & + & + & - \\
\hline 4-7 days & + & + & - & - & + & - & + & - & - \\
\hline 8 days & - & - & - & - & - & - & - & - & + \\
\hline Growth on $\mathrm{MPA}^{b}$ & - & - & - & + & - & - & $\mathrm{d}$ & + & - \\
\hline \multicolumn{10}{|l|}{ Intrinsic antibiotic resistance } \\
\hline Ampicillin, $10 \mathrm{mg} /$ liter & d & - & + & + & $\mathrm{d}$ & + & $\mathrm{d}$ & $\mathrm{d}$ & - \\
\hline Kanamycin, 25 mg/liter & $\mathrm{d}$ & - & - & - & $\mathrm{d}$ & + & - & - & + \\
\hline Penicillin, $10 \mathrm{mg} /$ liter & $\mathrm{d}$ & - & $\mathrm{d}$ & + & + & + & + & - & - \\
\hline Rifampin, 5 mg/liter & $\mathrm{d}$ & - & - & - & + & - & - & + & + \\
\hline Streptomycin, $25 \mathrm{mg} /$ liter & - & - & - & $\mathrm{d}$ & $\mathrm{d}$ & $\mathrm{d}$ & $\mathrm{d}$ & + & + \\
\hline $\mathrm{NaCl}(1.5 \%)$ tolerance & $\mathrm{d}$ & $\mathrm{d}$ & + & + & $\mathrm{d}$ & + & $\mathrm{d}$ & + & - \\
\hline \multicolumn{10}{|l|}{ Reaction with litmus milk } \\
\hline Acidification of medium & - & - & - & $\mathrm{d}$ & - & - & d & + & - \\
\hline Serum zone & + & d & - & + & + & + & + & + & - \\
\hline Growth at $37^{\circ} \mathrm{C}$ & $\mathrm{d}$ & - & $d$ & + & $\mathrm{d}$ & $\mathrm{d}$ & + & + & + \\
\hline \multicolumn{10}{|l|}{$\begin{array}{l}\text { Utilization of the following amino acids as } \\
\text { sole nitrogen and carbon sources: }\end{array}$} \\
\hline DL-Valine & $\mathrm{d}$ & d & $\mathrm{d}$ & + & + & + & + & + & + \\
\hline DL-Serine & $\mathrm{d}$ & $\mathrm{d}$ & + & + & $\mathrm{d}$ & + & + & + & + \\
\hline \multicolumn{10}{|l|}{ Utilization of the following carbon sources: } \\
\hline D-Arabinose & + & $\mathrm{d}$ & + & + & + & + & + & + & + \\
\hline D-Xylose & $\mathrm{d}$ & + & $\mathrm{d}$ & $\mathrm{d}$ & + & + & + & + & + \\
\hline
\end{tabular}

$a+$, at least $95 \%$ of the strains are positive; - , at least $95 \%$ of the strains are negative; $d$, less than $95 \%$ but more than $5 \%$ of the strains are positive.

${ }^{b}$ MPA, meat-peptone agar.

The present work also shows that, in general, the numerical classification of the Rhizobium species used in this study placed them into the same groups as methods based on genomic relatedness. Thus, on the basis of its phenotypic characters, the broad-host-range strain NGR 234 was closely related to the fast-growing soybean microsymbiont $R$. fredii USDA 191 (cluster 3 ), consistent with the results obtained by others from a comparison of $16 \mathrm{~S}$ rRNA sequences (7). The other $R$. fredii strain, which originates from India, was grouped with the $R$. meliloti strains (cluster 5), and this is also in agreement with the published phylogenetic data for these two species $(7,30,35)$. Strains of $R$. loti showed a close phenotypic relatedness to strains of $R$. huakuii (cluster 6, excepting strain CCBAU 2604), which also in accordance with results obtained previously by using 16S rRNA sequence comparisons $(20,31)$. The type strains of $R$. loti and $R$. huakuii however, had no more than $33 \%$ similarity to the Rhizobium strains isolated from $L$. corniculatus nodules used in this analysis.

In contrast to the similarities between the present work and the other work cited above, our dendrogram showed that $R$. tropici CIAT 899 was linked with $A$. tumefaciens C58 (biovar 1) (cluster 2). 16S rRNA sequence analysis indicates that this strain is more related to Agrobacterium sp. biovar 2 or $R$. leguminosarum than it is to Agrobacterium sp. biovar $1(14,16$, $23,31)$. Nevertheless, the symbiotic plasmid of CIAT 899 can be expressed in an $A$. tumefaciens $\mathrm{C} 58$ genetic background (15), and this fact suggests a degree of phenotypic relatedness between these two strains.

The metabolic properties of the $R$. galegae strains were closely related to those of Agrobacterium strains (cluster 4). The precise taxonomic position of the $R$. galegae strains is not yet clear. There is some evidence of their phylogenetic linkage to $R$. loti strains (36), but other authors showed them to be divergent from $R$. loti and demonstrated that they were more closely related to Agrobacterium species (23, 31). The results of mobilization of symbiotic genes from $R$. galegae into Agrobacterium strains would seem to support the second finding (18). In any case, formal taxonomic conclusions must be supported with data obtained by different systematic approaches. To conclude whether the temperatezone legume Rhizobium strains should be assigned to a new species of the genus or to $R$. loti will require further phylogenetic study. 
TABLE 4. Plant host ranges of Rhizobium strains isolated from root nodules of Astragalus, Oxytropis, and Coronilla plants

\begin{tabular}{|c|c|c|c|c|c|c|c|c|c|c|c|}
\hline \multirow[b]{2}{*}{$\begin{array}{c}\text { Host genus and } \\
\text { Rhizobium sp. strain }\end{array}$} & \multicolumn{10}{|c|}{ Nodulation ${ }^{a}$ of the following plant host: } & \\
\hline & 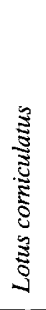 & 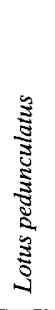 & 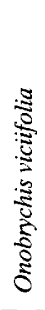 & 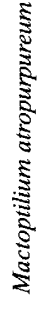 & 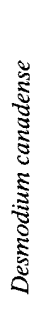 & 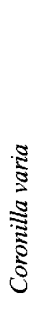 & 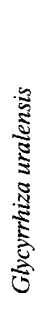 & 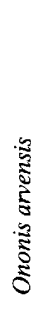 & 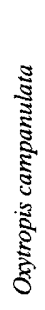 & 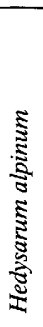 & \\
\hline \multicolumn{11}{|l|}{ Astragalus } & \\
\hline A11 & 0 & 0 & 0 & I & I & 0 & $\mathrm{E}$ & I & E & $\mathrm{E}$ & \\
\hline A23 & 0 & 0 & 0 & 0 & 0 & I & I & $\mathrm{E}$ & $\mathrm{E}$ & I & $\mathrm{E}$ \\
\hline CIAM 0212 & 0 & I & I & 0 & I & 0 & I & $\mathrm{E}$ & $\mathrm{E}$ & $\mathrm{E}$ & $\mathrm{E}$ \\
\hline CIAM 0213 & $\mathrm{E}$ & I & 0 & I & I & 0 & $\mathrm{E}$ & I & E & $\mathrm{E}$ & $\mathrm{E}$ \\
\hline CIAM 0214 & $\mathrm{E}$ & I & 0 & 0 & 0 & 0 & $\mathrm{E}$ & I & E & $\mathrm{E}$ & I \\
\hline CIAM 0219 & 0 & I & 0 & I & I & 0 & I & $\mathrm{E}$ & E & I & I \\
\hline \multicolumn{11}{|l|}{ Oxytropis } & \\
\hline CIAMM 2209 & $\mathrm{E}$ & I & 0 & 0 & 0 & 0 & E & $\mathrm{E}$ & E & $\mathrm{E}$ & $\mathrm{E}$ \\
\hline CIAM 2210 & E & I & I & 0 & I & 0 & $\mathrm{E}$ & I & $\mathrm{E}$ & $\mathrm{E}$ & $\mathrm{E}$ \\
\hline 256 & E & 0 & I & I & I & 0 & $\mathrm{E}$ & 0 & $\mathrm{E}$ & $\mathrm{E}$ & $\mathrm{E}$ \\
\hline \multicolumn{11}{|l|}{ Coronilla } & \\
\hline CIAM 3401 & 0 & 0 & 0 & $\mathrm{E}$ & 0 & E & $\mathrm{E}$ & 0 & 0 & 0 & I \\
\hline CIAM 3402 & 0 & 0 & 0 & 0 & 0 & $\mathrm{E}$ & I & 0 & 0 & 0 & I \\
\hline NZP 5462 & $\mathrm{E}$ & $\mathrm{E}$ & $\mathrm{E}$ & $\mathrm{E}$ & 0 & $\mathrm{E}$ & $\mathrm{E}$ & I & $\mathrm{E}$ & I & $\mathrm{E}$ \\
\hline
\end{tabular}

${ }^{a}$ E, effective symbiosis; I, ineffective symbiosis; 0, no nodules.

\section{ACKNOWLEDGMENTS}

We are grateful to Kristina Lindstrom and En-Tao Wang for kindly providing rhizobia strains, Yury Soskov for legume seeds, Esperanza Martinez for encouraging discussion, and Michael Dunn for reading the manuscript. 2000."

This work was supported by the Research Program "Interbioazot-

\section{REFERENCES}

1. Allen, O. N., and E. K. Allen. 1981. The Leguminosae: a source book of characteristics, uses and nodulation. Wisconsin University Press, Madison.

2. Bouzar, H., and L. W. Moore. 1987. Isolation of different Agrobacterium biovars from a natural oak savanna and tallgrass prairie. Appl. Environ. Microbiol. 53:717-721.

3. Chen, W. X., G. S. Li, Y. L. Qi, E. T. Wang, H. L. Yuan, and J. L. Li. 1991. Rhizobium huakuii sp. nov. isolated from root nodules of Astragalus sinicus. Int. J. Syst. Bacteriol. 41:275-280.

4. Crow, V. L., B. D. W. Jarvis, and R. M. Greenwood. 1981. Deoxyribonucleic acid homologies among acid-producing strains of Rhizobium. Int. J. Syst. Bacteriol. 31:152-172.

5. Eardly, B. D., J. P. W. Young, and R. S. Selander. 1992. Phylogenetic position of Rhizobium sp. strain Or 191, a symbiont of both Medicago sativa and Phaseolus vulgaris, based on partial sequences of the 16S rRNA and nifH genes. Appl. Environ. Microbiol. 58:1809-1815.

6. Elkan, G. H., and C. R. Bunn. 1992. The rhizobia, p. 2197-2213. In A. Balows, H.-G. Truper, M. Dworkin, H. Harder, and K.-H. Scleifer (ed.), The prokaryotes. A handbook on the biology of bacteria: ecophysiology, isolation, identification, applications, 2nd ed., vol. III. Springer-Verlag, New York.

7. Jarvis, B. D. W., H. L. Downer, and J. P. W. Young. 1992. Phylogeny of fast-growing soybean-nodulating rhizobia supports synonymy of Sinorhizobium and Rhizobium and assignment to Rhizobium fredii. Int. J. Syst. Bacteriol. 42:93-96.

8. Jarvis, B. D. W., M. Gillis, and J. De Ley. 1986. Intra- and intergeneric similarities between the ribosomal ribonucleic acid cistrons of Rhizobium and Bradyrhizobium species and some related bacteria. Int. J. Syst. Bacteriol. 36:129-138.

9. Jarvis, B. D. W., C. E. Pankhurst, and J. J. Patel. 1982. Rhizobium loti, a new species of legume root nodule bacteria. Int. J. Syst. Bacteriol. 32:378-380.

10. Jordan, D. C. 1984. Family III: Rhizobiaceae Conn 1938, p. 234-244. In N. R. Krieg and J. G. Holt (ed.), Bergey's mannual of systematic bacteriology. vol. 1. Williams \& Wilkins, Baltimore.

11. Krieg, N. R. 1981. Systematics V., p. 407-472. In P. Gerhardt, R. G. E. Murray, R. N. Costilow, E. W. Nester, W. A. Wood, N. R. Krieg, and G. B. Phillips (ed.), Manual of methods for general bacteriology. American Society for Microbiology, Washington, D.C.

12. Laguerre, G., M. P. Fernandez, V. Edel, P. Normand, and N. Amarger. 1993. Genomic heterogenity among French Rhizobium strains isolated from Phaseolus vulgaris L. Int. J. Syst. Bacteriol. 43:761-767.

13. Lindström, K. 1989. Rhizobium galegae, a new species of legume root nodule bacteria. Int. J. Syst. Bacteriol. 39:365-367.

14. Martínez, E. 1994. Recent developments in Rhizobium taxonomy. Plant Soil 161:11-20.

15. Martínez, E., R. Palacios, and F. Sanchez. 1987. Nitrogen-fixing nodules induced by Agrobacterium tumefaciens harboring Rhizobium phaseoli plasmids. J. Bacteriol. 169:2828-2834.

16. Martínez-Romero, E., L. Segovia, F. M. Mercante, A. A. Franco, P. Graham, and M. A. Pardo. 1991. Rhizobium tropici, a novel species nodulating Phaseolus vulgaris $\mathbf{L}$. beans and Leucaena sp. trees. Int. J. Syst. Bacteriol. 41:417-426.

17. Novikova, N. I., E. A. Pavlova, and E. V. Limeshchenko. 1993. Phage sensitivity and host range of Rhizobium strains isolated from root nodules of temperate legumes. Plant Soil 151:45-53.

18. Novikova, N. I., and V. I. Safronova. 1992. Transconjugants of Agrobacterium radiobacter harbouring sym genes of Rhizobium galegae can form an effective symbiosis with Medicago sativa. FEMS Microbiol. Lett. 93:261-268.

19. Orso, S., M. Gouy, E. Navarro, and P. Normand. 1994. Molecular phylogenetic analysis of Nitrobacter spp. Int. J. Syst. Bacteriol. 44:83-86.

20. Otten, L., J. Canaday, J.-G. Gérard, P. Fournier, P. Crouzet, and F. Paulus. 1992. Evolution of agrobactera and their Ti plasmids. Mol. Plant Microbe Interact. 5:279-287.

21. Prevóst, D., L. M. Bordeleau, S. Caudry-Reznick, H. M. Schulman, and H. Antoun. 1987. Characteristics of rhizobia isolated from 
three legumes indigenous to the Canadian high arctic: Astragalus alpinus, Oxytropis maydelliana and Oxytropis arctobia. Plant Soil 98:313-324.

22. Rinaudo, G., S. Orenga, M. P. Fernandez, H. Meugnier, and R. Bardin. 1991. DNA homologies among members of the genus Azorhizobium and other stem- and root-nodulating bacteria isolated from the tropical legume Sesbania rostrata. Int. J. Syst. Bacteriol. 41:114-120.

23. Sawada, H., H. Ieki, H. Oyaizu, and S. Matsumoto. 1993. Proposal for rejection of Agrobacterium tumefaciens and revised descriptions for the genus Agrobacterium and for Agrobacterium radiobacter and Agrobacterium rhizogenes. Int. J. Syst. Bacteriol. 43:694-702.

24. Scholla, M. H., and G. H. Elkan. 1984. Rhizobium fredii sp. nov., a fast-growing species that effectively nodulates soybeans. Int. J. Syst. Bacteriol. 34:484-486.

25. Segovia, L., J. P. W. Young, and E. Martinez-Romero. 1993. Reclassification of American Rhizobium leguminosarum biovar phaseoli type I strains as Rhizobium etli sp. nov. Int. J. Syst. Bacteriol. 43:374-377.

26. Sneath, P. H., and R. B. Sokal. 1973. Numerical taxonomy. The principles and practices of numerical classification. W. H. Freeman \& Co., San Francisco.

27. Trinick, M. J. 1980. Relationships amongst the fast growing rhizobia of Lablab purpureus, Luecaena leucocephala, Mimosa spp., Acacia farnesiana and Sesbania grandiflora and their affinities with other rhizobial groups. J. Appl. Bacteriol. 49:39-53.

28. van Rysin, J. (ed.). 1977. Classification and clustering. Proc. Adv. Semin. Math. Res. Center, University of Wisconsin, Madison. Academic Press, New York.

29. Vincent, J. M. 1970. A manual for the practical study of root- nodule bacteria. IBP Handbook no. 15. Blackwell Scientific Publications, Oxford.

30. Wedlock, D. N., and B. D. W. Jarvis. 1986. DNA homologies between Rhizobium fredii, rhizobia that nodulate Galega sp., and other Rhizobium and Bradyrhizobium species. Int. J. Syst. Bacteriol. 37:550-558.

31. Willems, A., and M. D. Collins. 1993. Phylogenetic analysis of rhizobia and agrobacteria based on 16S rRNA gene sequences. Int. J. Syst. Bacteriol. 43:305-313.

32. Wong, F. Y. K., E. Stackebrandt, J. K. Ladha, D. E. Fleischman, R. A. Date, and J. A. Fruest. 1994. Phylogenetic analysis of Bradyrhizobium japonicum and photosynthetic stem-nodulating bacteria from Aeschynomene species grown in separated geographical regions. Appl. Environ. Microbiol. 60:940-946.

33. Yanagi, M., and R. Yamasato. 1993. Phylogenetic analysis of the family Rhizobiaceae and related bacteria by sequencing of $16 \mathrm{~S}$ rRNA gene using PCR and DNA sequencer. FEMS Microbiol. Lett. 107:115-120.

34. Yelton, M. M., S. S. Yang, S. A. Edie, and S. T. Lim. 1983. Characterization of an effective salt-tolerant, fast growing strain of Rhizobium japonicum. J. Gen. Microbiol. 129:1537-1547.

35. Young, J. P. W. 1992. Phylogenetic classification of nitrogen-fixing organisms, p. 43-86. In G. Stacey, R. H. Burris, and H. J. Evans (ed.), Biological nitrogen fixation. Chapman \& Hall, New York.

36. Young, J. P. W. 1993. Molecular phylogeny of rhizobia and their relatives, p. 587-592. In R. Palacios, J. Mora, and W. Newton (ed.), New horizons in nitrogen fixation. Kluwer Academic Publishers, Dordrecht.

37. Zhang, X., R. Harper, M. Karsisto, and K. Lindström. 1991. Diversity of Rhizobium bacteria isolated from the root nodules of leguminous trees. Int. J. Syst. Bacteriol. 41:104-113. 